\title{
Weight Gain and Plasma Cholesterol Concentration in Mojosari Ducks Fed Different Levels of Chitin Extracted from Crab Wastes
}

\author{
Wandira IA, Ichsan M, Wiryawan KG \\ Mataram University, Jl. Majapahit No. 62, Mataram 83125, Nusa Tenggara Barat, Indonesia \\ k_wiryawan@unram.ac.id
}

\begin{abstract}
High fat and cholesterol contents of eggs and meat of ducks may limit the consumption of people who are especially aware on health. Attempts to lower cholesterol levels in ducks can be done by incorporating chitin extracted from crab (Portunus pelagicus) wastes in the ration. The objective of this study was to evaluate the effects of different levels of chitin in diet for growing Mojosari ducks on growth and plasma cholesterol concentration. Forty unsexed two-month-old ducks were randomly assigned into four dietary treatments with ten ducks each. All ducks were reared in individual cage for five weeks. Each duck received one of four diets, i.e., the control diet (T0) consisted of ground yellow corn, concentrate, rice bran, crude palm oil and mineral and vitamin premixes, the control diet containing $1 \%$ chitin (T1); $2 \%$ chitin (T2); $3 \%$ chitin (T3). The results showed that ducks fed on diet containing $2 \%$ and $3 \%$ chitin consumed much higher $(\mathrm{P}<0.01)$ feed than those consumed diet without or containing only $1 \%$ chitin but there was no significant difference $(\mathrm{P}>0.05)$ in weight gain and feed conversion ratio among treatment means. Levels of dietary chitin did not significantly affect $(\mathrm{P}>0.05)$ concentration of total cholesterol (TC), high density lipoprotein (HDL), but tended to reduce $(P=0.24)$ low density lipoprotein (LDL), and triglycerides (TG) concentration in growing Mojosari ducks. It is concluded that levels of dietary chitin did not significantly affect total cholesterol (TC) and high density lipoprotein (HDL), but tended to reduce low density lipoprotein (LDL) and triglycerides (TG) concentration in growing ducks.
\end{abstract}

Key Words: Mojosari Duck, Chitin, Weight Gain, Plasma Cholesterol

\section{INTRODUCTION}

Ducks can be considered as potential sources of dietary protein for human in Indonesia. However, their relatively high content of fat and cholesterol in meat and eggs may limit their consumption, especially by health care people (Pagala \& Nur 2010; Aziz et al. 2012). Consumer's anxiety may be eliminated by production of duck egg containing high level of omega-3 fatty acids and low level of cholesterol by feeding ducks diets containing omega-3 fatty acid (Wiryawan et al. 2013) or chitin and its derivatives.

Chitin is obtained from discarded shrimp and crab (Portunus pelagicus) exoskeletons or wastes by demineralization (Knorr 1991; Rochima 2014). The amount of these wastes steadily increases from year to year in line with the increasing production of this crab (BPS 2015) but has not been optimally used, even some of it pollute the environment (Rochima 2014). Chitin and its derivatives - as a potential resource as well as multiple functional substrates-have generated attractive interest in various fields such as biomedical, pharmaceutical, food and environmental industries, since the first isolation of chitin in 1811 (Park \& Kim 2010). However their use in order to reduce cholesterol in poultry products is very limited. Feeding chitin containing diet has been shown to reduce plasma cholesterol in broiler chicken (Razdan \& Petterson 1994; Hossain \& Blair 2007) and in rats (Gallaher et al. 2000; Warsono et al. 2004). Information regarding effects of dietary chitin on growth and plasma cholesterol in ducks need to be elucidated. The objectives of 
this study was to evaluate the effects of levels of chitin extracted from crab (Portunus pelagicus) wastes on weight gain and plasma cholesterol in growing Mojosari ducks.

\section{MATERIAL AND METHODS}

A total of 40 two-months-old Mojosari ducks with an average weight of $1047 \pm 83 \mathrm{~g}$ were randomly allocated into 4 dietary treatments with 10 ducks each. The ducks were housed in individual wire cage at an average temperature of $30^{\circ} \mathrm{C}$ for 5 weeks. The basal diet (T0) consisted of ground yellow corn, rice bran, commercial protein concentrate, crude palm oil and mineral/vitamin mixture (Table 1). Chitin was extracted from crab (Portunus pelagicus) meat processing wastes by means of demineralization using $10 \%$ $\mathrm{HCl}$ according to the method as described by Rochima (2014), and included in the feed at $1 \%$ (T1), $2 \%$ (T2), and 3\% (T3) at the expense of corn.

Table 1. The composition of dietary treatment

\begin{tabular}{lrrrr}
\hline \hline \multirow{2}{*}{ Feed ingredients $(\%)$} & \multicolumn{4}{c}{ Dietary treatments } \\
\cline { 2 - 5 } & T0 & T1 & T2 & T3 \\
\hline Corn & 50 & 49 & 48 & 47 \\
Rice bran & 17 & 17 & 17 & 17 \\
Commercial protein concentrate & 31 & 31 & 31 & 31 \\
Crude palm oil & 1 & 1 & 1 & 1 \\
Mineral/vitamin premix* & 1 & 1 & 1 & 1 \\
Chitin & 0 & 1 & 2 & 3 \\
Calculated nutrient & & & & \\
Crude protein & 18.04 & 18.12 & 18.20 & 18.29 \\
ME (kcal/kg) & 2818 & 2785 & 2752 & 2719 \\
Crude fiber & 4.81 & 4.99 & 5.17 & 5.35 \\
Crude fat & 6.39 & 6.35 & 6.30 & 6.26 \\
Ca & 3.59 & 3.59 & 3.59 & 3.59 \\
P & 0.78 & 0.77 & 0.77 & 0.77 \\
\hline
\end{tabular}

*Commercial vitamin premix, per $1 \mathrm{~kg}$ contains $48-50 \% \mathrm{Ca} ; 13-15 \% \mathrm{P} ; 40,000 \mathrm{mg} \mathrm{Fe} ; 27,500 \mathrm{mg}$ Mn; $500 \mathrm{mg}$ Iodine; 2,000 mg Cu; 25,000 mg Zn; $4.50 \mathrm{mg}$ Vitamin B12; $500.00 \mathrm{IU}$ Vitamin D3

Feed was mixed with water at a ratio of 2:1 prior to feeding and provided ad libitum and drinking water was always available. Feed consumption was measured daily, but the duck were weighed weekly.

At the end of feeding trial blood samples were collected via brachial vein from 5 ducks after an overnight feed withdrawal into heparinized tubes for analyses of total cholesterol (TC), triglycerides (TG), high density lipoprotein (HDL), and low density liporotein (LDL). 


\section{Data analysis}

All data were analyzed by anova using the GLM procedure of the SAS ${ }^{\circledR}$ software (1990). The means value of four treatments were compared each other using the least significant difference assay.

\section{RESULTS AND DISCUSSION}

\section{Effect of dietary chitin on feed consumption, weight gain and feed conversion}

It can be seen in Table 2 that feed consumption increased along with increasing levels of chitin in the diets. Ducks received diet containing 2\% and 3\% chitin consumed much higher $(\mathrm{P}<0.01)$ feed than those consumed diet without or containing only $1 \%$ chitin. Diet containing $2 \%$ chitin might be more palatable than control diet because chitin extracted from crab (Portunus pelagicus) wastes has been shown to improve palatability of broiler chicken diet (Razdan \& Pettersson 1994) and rat (Wiyatna et al. 2006). There was no significant difference $(\mathrm{P}>0.05)$ in weight gain among treatment means and increasing the level of dietary chitin was not followed by higher weight gain.

Table 2. The effect of dietary chitin on feed consumption, feed conversion ratio of growing ducks

\begin{tabular}{|c|c|c|c|c|c|c|}
\hline \multirow{2}{*}{ Parameters } & \multicolumn{4}{|c|}{ Treatment of the addition of chitin } & \multirow{2}{*}{ SEM } & \multirow{2}{*}{$P$ value } \\
\hline & T0 & $\mathrm{T} 1$ & $\mathrm{~T} 2$ & $\mathrm{~T} 3$ & & \\
\hline Weight gain $(\mathrm{g})$ & 363.00 & 410.50 & 475.50 & 435.00 & 32.16 & 0.1256 \\
\hline Feed consumption (g) & $1410.70^{b}$ & $1489.50^{\mathrm{b}}$ & $1983.00^{\mathrm{a}}$ & $1838.00^{\mathrm{a}}$ & 112.30 & 0.0027 \\
\hline FCR & 3.94 & 3.76 & 4.25 & 4.24 & 0.21 & 0.3146 \\
\hline
\end{tabular}

${ }^{a, b}$ Means at the same row without a similar superscript are significantly different $(\mathrm{P}<0.05)$

SEM: Pooled Standard Error of the Means

These results are not in line with results from research carried out by Faisal \& Agusnar (2006) in which the addition of $1 \%$ chitin in chicken rations can increase the weight gain up to $29 \%$, but the chicken received diet with $1.5 \%$ chitin only $7.2 \%$ better than control. Further studies are still needed to elucidate effect of feeding chitin to ducks because results of several studies are still inconsistent. Shi-Bin \& Hong (2012), for example, reported a non significant different in weight gain of growing ducks (22-35 days old) given diets with $0.12 \%$ or $0.24 \%$ chitosan (chitin derivative).

Feed conversion ratio (FCR) poultry is a measure of bird efficiency in converting feed mass into increases of weight gain or amount of egg produced. Table 2 showed that FCR of ducks given diet without or with different levels of chitin were between 3.76-4.25. FCR was slightly $(7.8 \%)$ increased when the ducks were fed diet with $2 \%$ chitin. This might be associated with increasing concentration of dietary fiber. Fiber has been considered a diluent and an anti-nutritional factor in monogastric animals (Jimenez-Moreno 2014). High concentration of dietary fiber had a negative effects on growth performance (Swensen et al. 2010). Sklan et al. (2003) reported that increasing the crude fiber content of turkey diet from 3 to $9 \%$ has been shown to reduce weight gain and impaired nutrient retention.

\section{Plasma lipid concentrations}

The results of the analyses indicate that levels of dietary chitin did not significantly affect $(\mathrm{P}>0.05)$ total cholesterol (TC), high density lipoprotein (HDL), low density 
lipoprotein (LDL), and triglycerides (TG) concentration in growing ducks. Plasma concentrations of TC and HDL were relatively constant irrespective to increasing levels of dietary chitin. These results different with results reported by Pagala \& Nur (2010) showing that $1.5 \%$ supplementation of chitosan (chitin derivative) in the ration of ducks were able to lower the levels of TG up to $10.65 \mathrm{mg} / \mathrm{dl}$. Studies by Hossain \& Blair (2007) reported that plasma cholesterol and TG concentrations in liver and breast meat were significantly reduced by chitin inclusion. Similar patterns were also found in the study with rats as reported by Nasihun \& Widayati (2010).

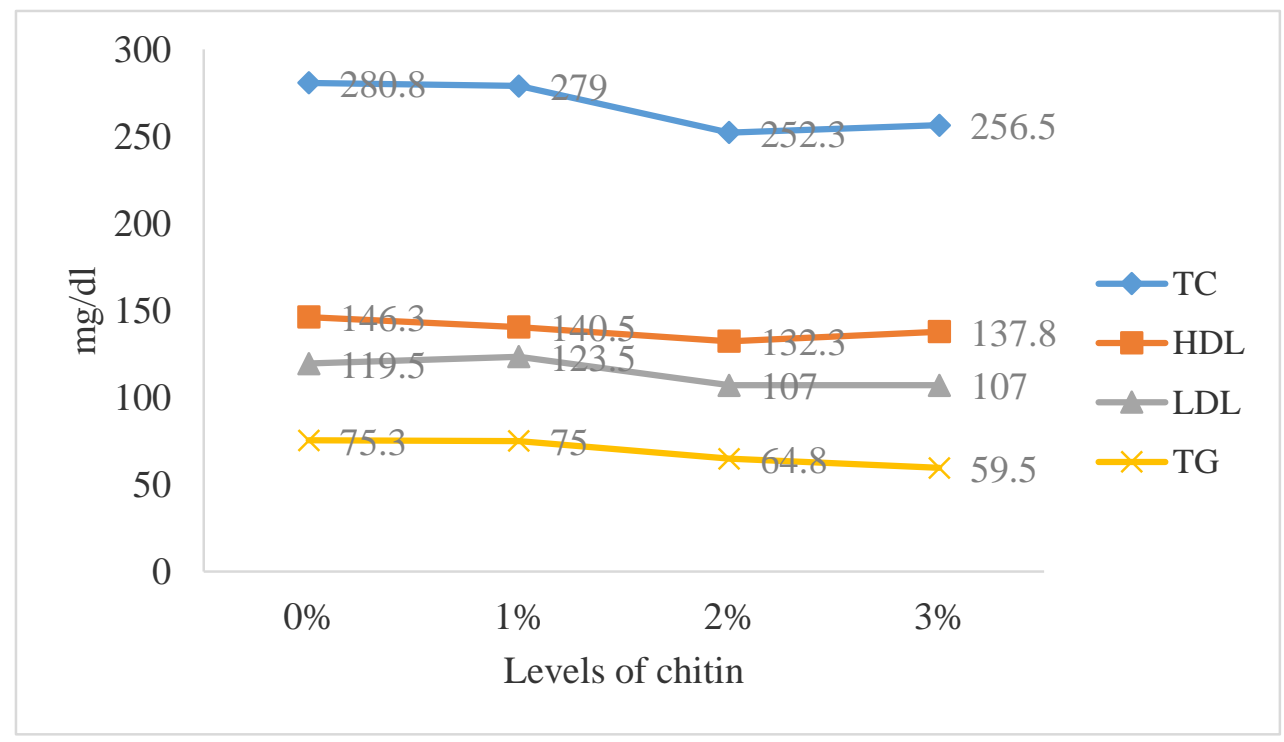

Figure 1. Effect of levels of dietary chitin on TC, HDL, LDL and TG in growing ducks

\section{CONCLUSION}

Mojosari ducks given diet containing 2\% and 3\% chitin consumed much higher feed than those fed on diet without or containing only $1 \%$ chitin but the weight gains were not significantly different. Levels of dietary chitin did not significantly affect total cholesterol (TC), high density lipoprotein (HDL), low density lipoprotein (LDL), and triglycerides (TG) concentration in growing ducks.

\section{REFERENCES}

Aziz Z, Cyriae S, Beena V, Philomina PT. 2012. Comparison of cholesterol content in chicken, duck and quail eggs. J Vet Anim. Sci.43:64-66.

BPS. 2015. Nusa Tenggara Barat dalam Angka Tahun 2014. Badan Pusat Statistik Nusa Tenggara Barat.

Faisal H, Agusnar H. 2006. Pengaruh penambahan kitin protein sebagai zat aditif pada makanan ternak untuk meningkatkan pertumbuhan ayam broiler. J Sains Kimia. 10:67-72.

Gallaher CM, Munion J, Hesslink R Jr, Wise J, Gallaher DD. 2000. Cholesterol reduction by glucomannan and chitosan is mediated by changes in cholesterol absorption and bile acid and fat excretion in rats. J Nutr Nov. 130:2753-2759.

Hossain SM, Blair R. 2007. Chitin utilisation by broilers and its effect on body composition and blood metabolites. Br Poult Sci. 48:33-8. 
Jimenes-Morino E, Mateos GG. 2014. Use of dietary fiber in broiler. [Internet]. [Cited 25 January 2016]. Available at :http://e.engormix.com/MA-poultry-industry/nutrition/articles/use-dietaryfiber-broiler-t3067/141-po-html.

Knorr D. 1991. Recovery and utilization of chitin and chitosan in food processing waste management. Food Technol. 45:114-122.

Nasihun TR, Widayati E. 2010. Lowering blood cholesterol levels resulted from sea-shrimp's shell supplementation (Palaemon sp.) in rats fed on pig oil. J Anti Hiperkolesterolemia Cangkang Udang Laut. 2:134-150.

Pagala MA, Nur I. 2010. Pengaruh kitosan asal cangkang udang terhadap kadar lemak dan kolesterol darah itik. Warta-Wiptek. 18:26-31.

Park BK, Kim MM. 2010. Applications of chitin and its derivatives in biological medicine. Int $\mathbf{J}$ Mol Sci. 11:5152-5164.

Razdan A, Petterson D. 1994. Effect of chitin and chitosan nutrient digestibility and plasma lipid concentration in broiler chicken. Br J Nutr. 72:277-288.

Rochima E. 2014. Kajian pemanfaatan limbah rajungan dan aplikasinya untuk bahan minuman kesehatan berbasis kitosan. J Akuatika 5:71-82.

SAS. 1990. SAS/STAT User's Guide, version 6, 4th ed. Vol. 2. Cary (USA): SAS Institute Inc. p. 891-996.

Shi-bin Y, Hong C. 2012. Effects of dietary supplementation of chitosan on growth performance and immune index in ducks. Afr J Biotechnol. 11:3490-3495.

Sklan D, Smirnov A, Plavnik I. 2003. The effect of dietary fiber on the small intestines and apparent digestion in the turkey. Br Poult Sci. 44:735-740.

Swennen Q, Everaert N, Debonne M, Verbaeys I, Careghi C, Tona K, Janssens GPJ, Decuypere E, Bruggeman V, Buyse J. 2010. Effect of macronutrient ratio of the prestarter diet on broiler performance and intermediary metabolism. J Anim Physiol Anim Nutr. 94:375-384.

Warsono IU, Fattah WM, Parakkasi A. 2004. Pengaruh tepung cangkang rajungan (Portunus pelagicus) dalam ransum terhadap kadar kolesterol serum dan pertambahan bobot badan tikus puth (Rattus norvegicus). Media Peternakan. 27:55-62.

Wiryawan KG, Hanartani, Samiadi 2013. Potensi minyak ikan dan rumput laut dalam pakan itik untuk menghasilkan telur omega. In: Muntari, Suana IW, Kisworo D, Muktasam, Fauzi T, Sustiawati L, Wiryawan KG, Prasiasa DPO, editors. Optimalisasi IPTEKS untuk pengembangan pariwisata yang berkelanjutan. Prosiding Seminar Nasional Pariwisata. Mataram 12 September 2013. Mataram (Indonesia): Universitas Mataram. p. 36-40.

Wiyatna MF, Warsono IU, Parakkasi A. 2006. The effect of crabs shells (Portunus pelagicus) as a source of chitin in ration on feed efficiency and fats of feces in rat (Rattus norvegicus) strain wistar. J Ilmu Ternak. 6:32-36. 